\title{
Analysis of Chemical Properties of Forest Soils from Bacau County
}

\author{
VLAD EMIL CRISAN ${ }^{*}$, LUCIAN CONSTANTIN DINCA ${ }^{1}$, SORIN STEFAN DECA ${ }^{2}$ \\ 1"Marin Dracea" National Institute for Research and Development in Forestry, 13 Closca Str., Brasov 500040, Romania \\ ${ }^{2}$ Romanian Academy of Advanced Studies, 125 Calea Victoriei Str., 10071, Bucharest, Romania
}

Abstract:State forests are analyzed periodically, once every 10 years. This includes an analysis of forest soils. The present paperdescribes and interprets the chemical properties of forest soils from Bacau County focusing on the period 1983-2015. As such, 823 soil profiles and 2435 pedogenetic horizons were analysed taking into consideration the soil type, $\mathrm{pH}$, humus content, nitrogen content, base saturation degree and the total cation exchange capacity. The most widespread types of soils are: eutriccambisol, luvisol, preluvisoland dystriccambisol. The dystriccambisols from Bacau County are strongly acid soils, while eutriccambisols and preluvisols are moderately acid. All forest soils from this area have a high cationic exchange capacity and are very well (dystriccambisol, eutriccambisol,luvisol) or well supplied (preluvisol, rendzina) with nitrogen. Knowing the chemical properties of soils is important for the analysis of stand variability and for adopting silvicultural methods adequate for the management of long-lasting forests.

Keywords:forest soils, Bacau county, soil reaction, nitrogen, humus.

\section{Introduction}

Bacau County occupies 2.8\% from Romania's total surface, namely 662,052 ha. The county's relief is relatively equally distributed between mountains, hills and plains. The highest altitude is 1,664 $\mathrm{m}$ in Tarcaului Mountains, while the lowest one which is $100 \mathrm{~m}$ can be found on Siretului Valley (Figure 1). Arable fields occupy $48.5 \%$ of the county's surface, followed by forests with $39.8 \%$ [1].The most widespread soil at a national level is dystric cambisol, followed byluvisolandeutriccambisol (Figure 1) [2].

State forests cover a surface of 174,267 ha, being managed by Bacau Forest District through its 14 Forest Districts:Bacau, Caiuti, Ciobanus, Comanesti, Darmanesti, Fantanele, Livezi, Manastirea Casin, Moinesti, Oituz, Sascut, TarguOcna, Traian andZeletin [3].
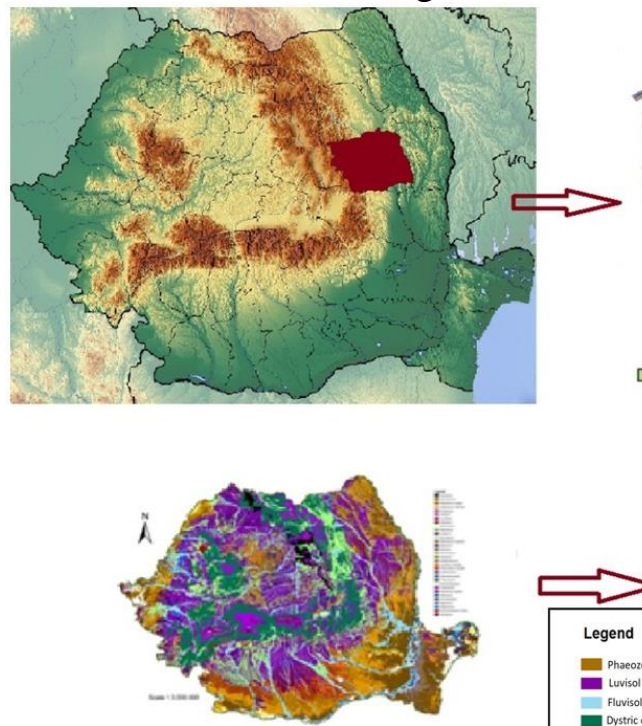
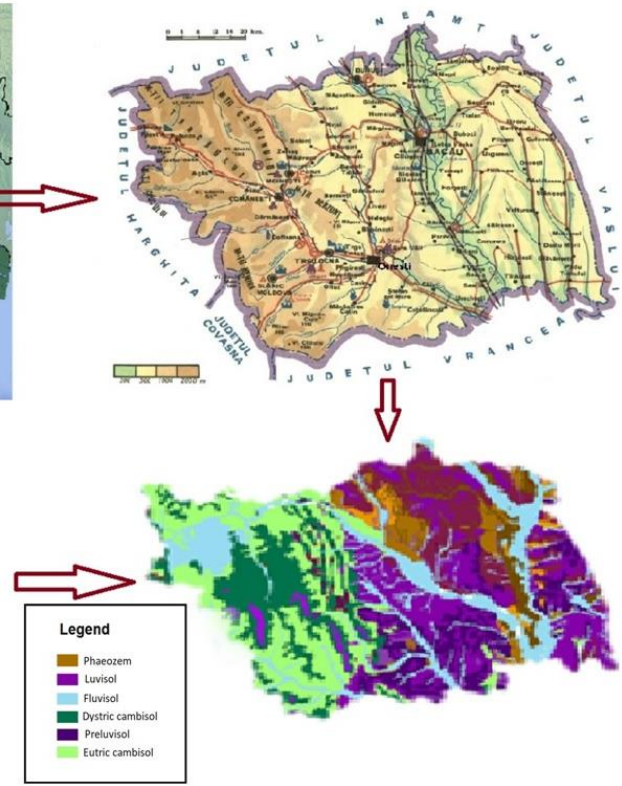

Figure 1. The soils from Bacau County [2]

*email:vlad_crsn@yahoo.com 


\section{Materials and methods}

Romanian forests are inventoried and described every ten years through forest management plans together with the description of all environment characteristics such as flora type, soil type or station type and stand factors like: age, diameter and height, volume, growth. In this context, the main soil types are also identified through control profiles placed in all parcels and main profiles from the representative areas. Usually there are made approximately 10-20 profiles in each forest district. Soil samples are collected from pedogenetic horizons and are analysed through performing analysis methods accordant with European methodologies [4-6].

We used thesoil analyses realized in the period 1984-2016 for 823 soil profiles [7]. The large number of measurements $(2,435$ for each chemical parameter) is the guarantee of a good statistical insurance of the results obtained. The following soil chemical parameters were analysed: soil reaction $(\mathrm{pH})$, base saturation degree $(\mathrm{V}, \%)$, total cationic exchange capacity ( $\mathrm{T}$, meq/100 g soil), humus content $(\mathrm{H}, \%)$ and total nitrogen content $(\mathrm{N}, \%)$.

Assessment methods of the investigation:The soil's $\mathrm{pH}$ was determined by potentiometric method (aqueous suspension, 1:2.5, w/v) the readings being fulfilled with a Thermo Orion $3 \mathrm{pH}-\mathrm{meter}$. The humus from the soil was established through the humid oxidation method and titrimetric dosage by Walkley-Black-Gogoasa method. The total nitrogen from the soil was established through the humid mineralization method and titrimetric dosage by Kjeldahl method with Gerhardt automatic analyser. The exchange acidity (Ac), the extract of potassium acetate and the basic cations $\left(\mathrm{K}^{+}, \mathrm{Na}^{+}, \mathrm{Mg}^{++}\right.$, $\mathrm{Ca}^{++}$) were determined through the repeated bleeders with ammonium acetate. The total cationic exchange capacity (T) was calculated by summing $\mathrm{Ac}, \mathrm{K}^{+}, \mathrm{Na}^{+}, \mathrm{Mg}^{++}$and $\mathrm{Ca}^{++}$. The base saturation degree was calculated using the following equation (1):

$$
\mathrm{V}=\frac{(K+, N a+, M g++, C a++)}{T} \times 100
$$

\section{Results and discussions}

The most widespread type of soil areeutriccambisoland luvisol, both soils occupying 55\%, which means more than half of the Bacau county forest surface (Figure 2). Lower surfaces are occupied by dystric cambisol, preluvisol, rendzina, phaeozem. There are also other soilswhich together occupy less than 3\% from county's total forest surface like:fluvisol, chernozem, gleysol, regosol andsolonchak (Figure 2). In Bacau County, the difference from the national average is represented by the preponderance of eutriccambisolinstead of dystric cambisol, due to an increased presence of premountain and low mountain areas in comparison with the superior mountain area where dystric cambisols prevail. In comparison with other areas from our country like Braila County[8], chernozem and phaeozem soils occupy narrower areas in Bacau County.

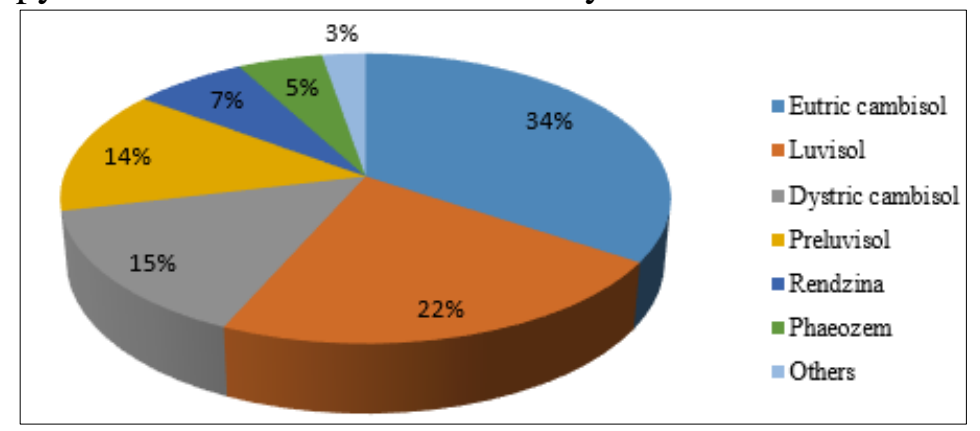

Figure 2.Types of forest soils from Bacau County

Eutriccambisolis a soil characteristic to the inferior mountain level [9,10], a level named "pedocambic level" by N. Barbuin 1987 [11] due to the predominant presence of these soils. Luvisol is 
spread out in hill and plateaus or high fields[12], while dystric cambisol occupies inferior and superior mountain areas(Fig. 3) [13, 14].

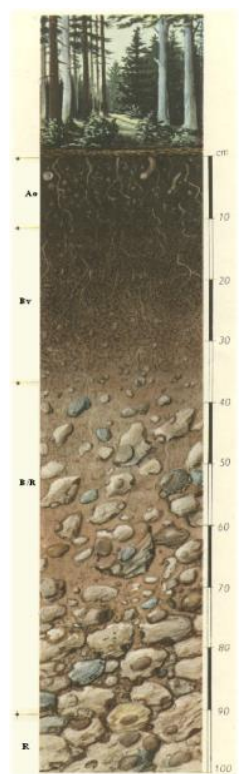

Eutriccambisol

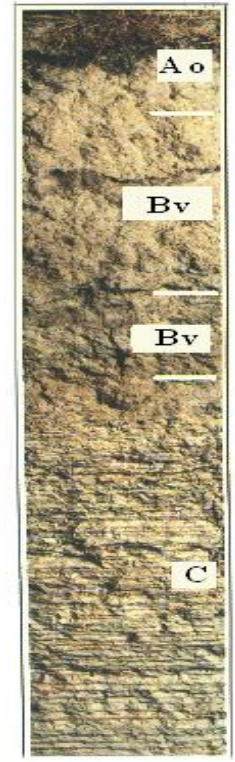

Figure 3. The main forest soils from Bacau County [14-15]

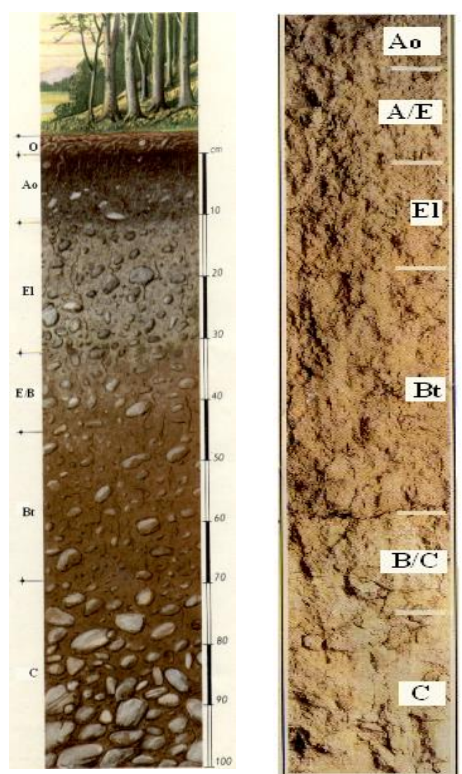

Luvisol
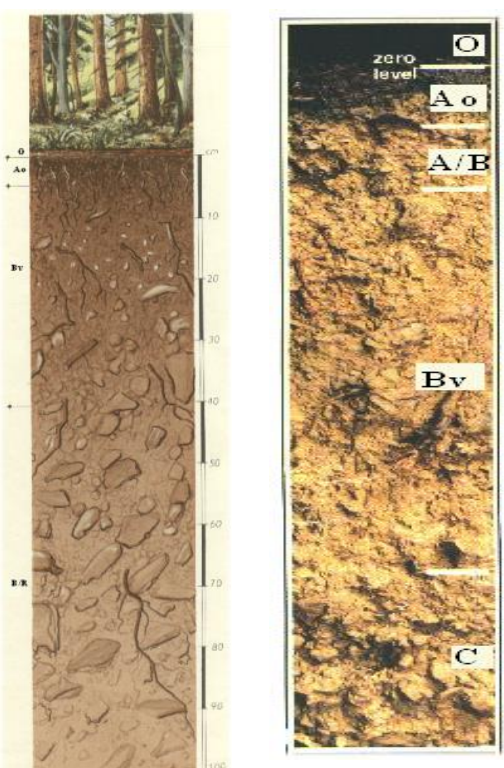

Dystric cambisol

In Bacau's agricultural fields, preluvisol occupies 23\%, regosol 14\%, luvisol $11 \%$, eutriccambisol $11 \%$, and cambic chernozem 4\% [16]. For the entire county's surface whichincludes both forest soils, agricultural soils and non-productive fields, the hierarchy of soil types is the following: preluvisol $23 \%$, luvisol 18\%, regosol 16\%, eutriccambisol 15\%, fluvisol 7\%, and dystric cambisol 7\% [17]. The predominant soils from the Moldavian SubCarpathian Slot are: luvisol (37,155 ha), chernozem (21,731 ha), regosol (20,092 ha), preluvisol (19,631 ha), fluvisol (18,387 ha), phaeozem (9,966 ha), and eutriccambisol (9,729 ha) [18].

Dystric cambisols from Bacau County are strongly acid soils, while eutriccambisols and luvisols are moderately acid. Phaeozem is neutral in the A/C horizon and weakly alkaline in the $\mathrm{C}$ horizon. For rendzina, in Bacau County, soil solution reaction varies between weakly acid and weakly alkaline (Figure 4).

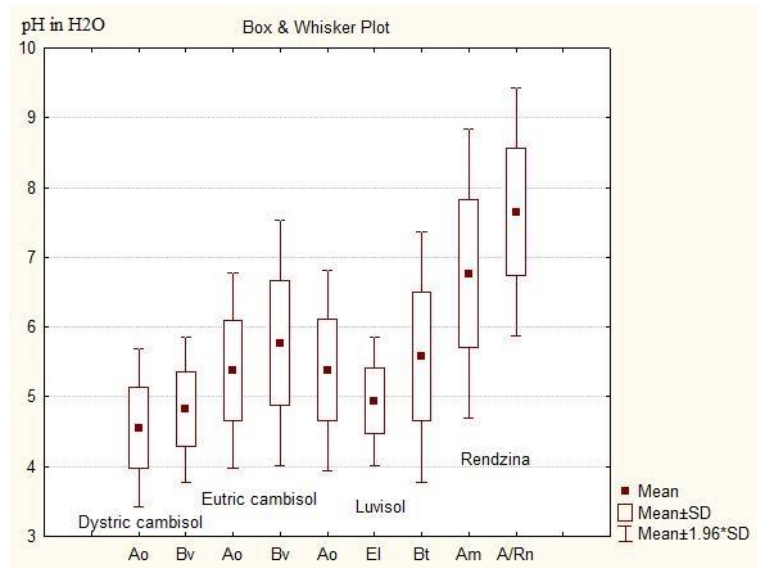

Figure 4. $p \mathrm{H}$ variation of genetic horizons for the most widespread forest soils from Bacau County

Regarding agricultural soils from Bacau County, moderately acid soils occupy $18 \%$, followed by the weakly acid ones (41\%), neutral (9\%), weakly alkaline (31\%) and moderately alkaline (1\%) [16]. 


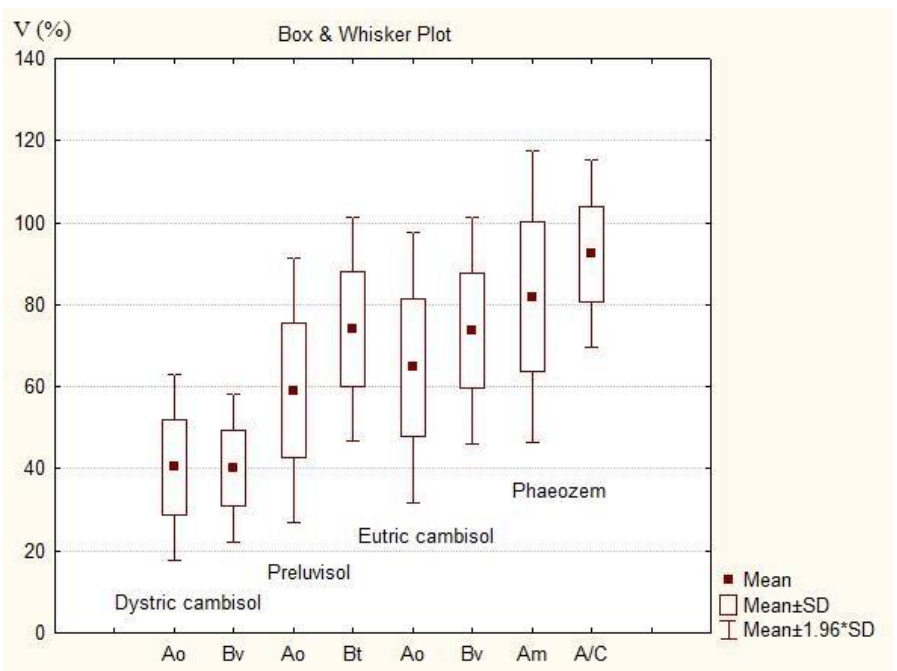

Figure 5. Base saturation degree variation for the most widespread soils from Bacau County

Dystric cambisolsare oligo-mesobasic, while preluvisols and eutriccambisolsaremesobasic and phaeozem is eubasic (Figure 5). In Maramures County, eutriccambisols are also mesobasic[19]while in Cluj County preluvisolsare mesobasic[20].

The total exchange capacity has the highest values in rendzina, while the lowest ones were found for preluvisol (Table 1). It is well known that cation exchange capacity depends on the stabilizing capacity of different size fractions [21, 22], a fact that explains these differences. However, the factor that most influences total cation exchange capacity is the quantity of organic matter from the soil [23, 24], calculus also shows that the soil with the smallest cation exchange capacity (preluvisol) also has the lowest quantity of humus.

Table 1. Total cation exchange capacity and average humus and nitrogen content for forest soils from Bacau County

\begin{tabular}{|c|c|c|c|c|c|}
\hline Eutriccambisol & $\begin{array}{c}\text { Dystric } \\
\text { cambisol }\end{array}$ & Preluvisol & Luvisol & Rendzina & Phaeozem \\
\hline \multicolumn{6}{|c|}{ Total cation exchange capacity (Tmeq/100 g soil) } \\
\hline 22.68 & 20.84 & 19.80 & 21.68 & 30.25 & 24.25 \\
\hline \multicolumn{6}{|c|}{ Average humus content in the A horizon $(\mathrm{H} \%)$} \\
\hline 5.59 & 6.62 & 4.01 & 5.75 & 4.11 & 4.32 \\
\hline \multicolumn{6}{|c|}{ Average nitrogen content in the A horizon $(\mathrm{N} \%)$} \\
\hline 0.36 & 0.35 & 0.21 & 0.31 & 0.21 & 0.19 \\
\hline
\end{tabular}

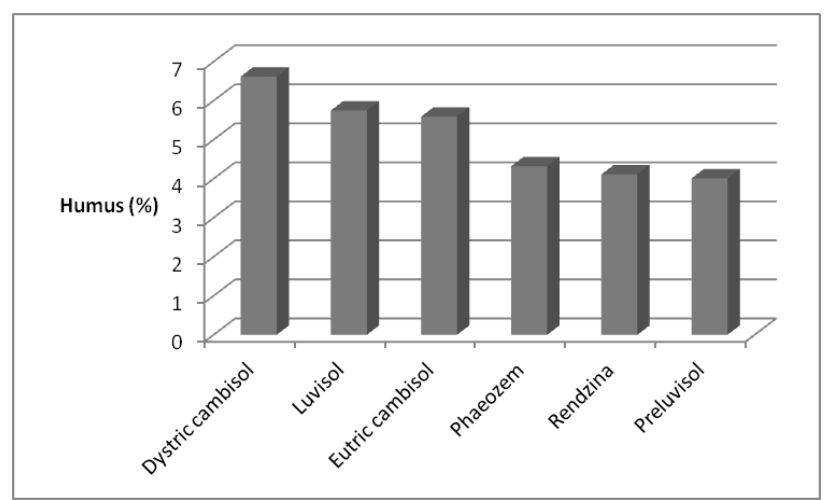

Figure 6. The variation of humus content for the most widespread forest soils from Bacau County

Half of the forest soils from this area are intensely humiferous:distryccambisol,luvisol and eutriccambisol, whilepreluvisol, phaeosem and rendzina are moderately humiferous (Fig. 6). 
The humus content for agricultural soils from Bacau County is distributed as follows: very weak $(6 \%)$, weak (58\%), average (31\%) and high (5\%) [16]. For the forest soils, the average values from other areas of the country show that eutriccambisol and preluvisolcan be moderately humiferous in Romanian West Plain[25], while luvisols can be intensely humiferous in Arges[26].

The most well-supplied forest soils with nitrogen from Bacau County areeutriccambisoland dystric cambisol.Rendzina and preluvisol are well supplied with nitrogen, while the poorest oneisphaeozem.The nitrogen quantity from the soil depends on the type of land use [27], vegetation type[28], orsoil water content [29].Other forest soils from the country like eutriccambisols and preluvisolsfrom Arad region are also well-supplied with nitrogen[30].

\section{Conclusions}

The biodiversity of forest soils from Bacau County is high. As such, the soils from the mountain area (dystric cambisol, rendzina), hills area (eutriccambisol, luvisol) and plain area (preluvisol,phaeozem) were inventoried. Based on this analysis, the most widespread types of soils from this forest area are eutriccambisol and luvisol. Eutriccambisolis moderately acid, with a high total cationic exchange capacity and intensely humiferous. Dystric cambisolis strongly acid, oligomesobasic, with a high total cationic exchange capacity and intensely humiferous. Preluvisol is moderately acid, oligo-mesobasic, with an average total cationic exchange capaticy and moderately humiferous. Luvisol is moderately acid, oligo-mesobasic, with a high total cationic exchange capacity and intensely humiferous. Rendzina is a neutrally-weak alkaline soil, with a very high total cationic exchange capacity and moderately humiferous.

Knowing and understanding the chemical properties of soils from this area, with a considerable percentage in the national forest fund, is useful for future soil deficits that can affect forest vegetation. Furthermore, this extends towards the adoption of proper and performing silvicultural measures corresponding to the requests of species for certain soil characteristics.

\section{References}

1.***Insee, Available online:https://www.bacau.insse.ro/wp-content/uploads/2018/07/Anuar2017.pdf. (accessed 15.01.2020)

2. DINCĂ, L., SPÂRCHEZ, G., DINCĂ, M.,Romanian's forest soil GIS map and database and their ecological implications, Carpat.J.Earth Envi. Sci., 9(2), 2014,133-142.

3. Romsilva, Available online:http://www.rosilva.ro. (accessed 15.07.2019)

4. DINCA, L., LUCACI, D., IACOBAN, C., IONESCU, M., Methods of analysis of properties and soil solution, (in roumanian: Metode de analiză a proprietăţilorşisoluţieisolurilor), EdituraTehnica Silvică, Bucureşti, 2012, 173.

5. ONET, A., DINCA, L., TEUSDEA, A., CRIȘAN, V., BRAGĂ, C., ENESCU, R., ONET C.,The influence of fires on the biological activity of forest soils in vrancea, Romania, Environ. Eng.And Manag.Jou., 18(12), 2019, 2643-2654.

6. MUSCALU (PLESCAN), O.-M., NEDEFF V., SANDU, I., CHITIMUS, A.D., PARTAL, E., MOSNEGUTIU,E., SANDU, I.G., TOMOZEI, C., Influence of Soil Fertilization Systems on Chemical Properties of the Soil, Rev.Chim., 70(12), 2019,4557-4565.

7. ***Forest management plans: Ciobanus (1984, 2016); Bacău (2009); Căiuți (1987, 2007); Comanesti (1984, 1995,2016); Darmanesti (1984, 2006, 2016); Fântânele (1988, 1999, 2008); Livezi (2008); MănăstireaCașin (1987,2007); Moinesti (1985, 1995, 2005, 2015); Oituz (1986, 2006, 2016); Sascut (2009); TarguOcna (2006, 2016); Traian (1998, 2008); Zeletin (2009).

8. CRIȘAN, V., DINCA, L., ONET, A., ONET, C., The description of forest soils from Brăilacounty. Nat.Res. Sust.Dev., 2017, 21-26.

9. FLOREA, N., UNTARU G., VESPREMEANU R., MOTELICĂ D.,Distributiacantitativa a solurilor in principaleleunitati de relief din Romania, ŞtiinţaSol., 31(1), 1997, 57-70. 
10. ONET, A., DINCA, L.C., GRENNI, P., LASLO, V., TEUSDEA, A.C., VASILE, D.L., ENESCU, R.E., CRIȘAN, V.E., Biological indicators for evaluating soil quality improvement in a soil degraded by erosionprocesses. Jou. Soil Sed., 19(5), 2019, 2393-2404.

11. BARBU, N.,GeografiasolurilorRomaniei. Centrul de multiplicare a Universitatii A.I. Cuza., Iasi, 1987, 178.

12. FILIPOV, F.,Pedologie. Editura Ion Ionescu de la Brad, Iasi, 2005, 440.

13. BĂLĂCEANU, V., TAINĂ. S., CRĂCIUN, C.,Solurile brun acide dinRomania.Factoriși procesepedogenetice.EdituraUniversității Al. I. Cuza, Iași, 2002, 3-100.

14. TARZIU, D.R., SPÂARCHEZ, G., DINCA, L.,SolurileRomâniei,PentruViaţă Publishing House, Brasov, 2002,100.

15. CHIRITA, C.D., PAUNESCU, C., TEACI, D., Solurile României, Editura Agrosilvică, București, 1967, 241.

16. TROFIN, V., MARA, M., ALATEANU, M.,Romania's XVI National Conference of Soil Science, Suceava, Romania, (in Romanian: Ghidulcelei de a XVI-a ConferinţeNaţionale pentru Ştiinţa Solului, Suceava, Romania), Resursele de sol dinjudeţul Bacăa, 2000,55-66.

17. MARA, M., DARLAU, O.,Soil resources of Bacau County, Soil Form. Fact. Proc.Temp.,13, 2014, 59-66.

18. MARA, M., The soils types from Moldavian Sub-Carpathian slot, Soil Form. Fact. Proc.Temp., 4, 2005, 185-197.

19. CRISAN, V.E., ENESCU, R.E., DINCA, M., Descriereasolurilor din cadrulDirecţiilorSilvice Giurgiu si Maramureş (Soil description of the Forestry Directorates Giurgiu and Maramureș), Rev. Silv.Cin., 39, 2016, 85-89.

20. ENESCU, R.E., DINCA, L., LUCACI, D., The main characteristics of forest soils from Cluj and Harghita Counties, ProEnvi.,10(30), 2017, 57-61.

21. CARAVACA, F., LAX, A., ALBALADEJO, J.,Organic matter, nutrient contents and cation exchange capacity in fine fractions from semiarid calcareous soils, Geoderma, 93(3-4), 1999, 161176.

22. HEPPER, E.N., BUSCHIAZZO, D.E., HEVIA, G.G., URIOSTE, A., ANTON,L., Clay mineralogy, cation exchange capacity and specific surface area of loess soils with different volcanic ash contents, Geoderma, 135, 2006, 216-223.

23.AMINI, M., ABBASPOUR, K.C., KHADEMI, H., FATHIANPOUR, N., AFYUNI, M.,

SCHULIN, R.,Neural network models to predict cation exchange capacity in arid regions of Iran.Eur. J. SoilSci., 56(4), 2005, 551-559.

24. PARFITT, R. L., GILTRAP, D.J., WHITTON, J.S.,Contribution of organic matter and clay minerals to the cation exchange capacity of soils. Communic. soil sci. plant analy., 26(9-10), 1995, 1343-1355.

25. DINCĂ, L., CHISĂLIŢĂ, I., CANTAR, I.C., Chemical Properties of Forest Soils from Romania West Plain, Rev.Chim., 70(7), 2019, 2371-2374.

26. ENESCU, C.M., DINCA, L.,Forest soils from Arges County, Cur.Trend. Nat. Sci., 7(14), 2018, 176-182.

27. YIMER, F., LEDIN, S., ABDELKADIR, A.,Changes in soil organic carbon and total nitrogen contents in three adjacent land use types in the Bale Mountains, south-eastern highlands of Ethiopia., For.Eco.Manag., 242(2-3), 2007, 337-342.

28. FU, X., SHAO, M., WEI, X., HORTON, R.,Soil organic carbon and total nitrogen as affected by vegetation types in Northern Loess Plateau of China, Geoderma, 155(1-2), 2010, 31-35.

29. PAUL, K.I., POLGLASE, P.J., O'CONNELL, A.M., CARLYLE, J.C., SMETHURST, P.J., KHANNA, P.K., Defining the relation between soil water content and net nitrogen mineralization, Eur.J. Soil Sci., 54(1), 2003, 39-48.

30. CANTAR, I.C., DINCA, L.,The forest soils from Arad County, Ann. Univ. Craiova, 23(59), 2018, 345-351.

Manuscript received: 3.02 .2020 